$\begin{array}{cl}\text { Türkiye Tarımsal Araştırmalar Dergisi } & \text { Turk J Agric Res } \\ \text { http://dergi.siirt.edu.tr } & \text { (2016) 3: 1-13 } \\ \text { O TüTAD } & \text { ISSN: 2148-2306 } \\ \text { Araștırma Makalesi / Research Article } & \text { 10.19159/tutad.55780 }\end{array}$

\title{
Samsun Terme Havzası Bazı Temel Fizyografik Karakteristikleri Belirlenmesi ve Tarımsal Taşkın Alanlarının Toprak Haritalanması*
}

\author{
Adem COŞKUN, Orhan DENGiZz* \\ Ondokuz Mayls Üniversitesi, Ziraat Fakültesi, Toprak Bilimi ve Bitki Besleme Bölümü, Samsun, TÜRKIYE
}

\begin{abstract}
Geliş Tarihi/Received: 05.10.2015
Kabul Tarihi/Accepted: 25.02 .2016

** Sorumlu yazar/Corresponding author: o_dengiz@hotmail.com

Özet: Yapılan bu çalışma ile ilk olarak Çarşamba Ovası'nın doğusunda kalan ve Terme Çayı'nın ovaya girdi noktadan denize döküldüğ̈̈ yere kadar olan $19 \mathrm{~km}$ mesafe içerisinde ve yaklaşık akarsuyun her iki yakasında yine yaklaşık $2.5 \mathrm{~km}$ genişlik kaplayan ve çoğunluğu düz eğime sahip $53.6 \mathrm{~km}^{2}$ alan içerisinde toprak, topografya, arazi kullanımı ve arazi örtüsü vb. karakteristiklerinin ortaya çıkartılması, ikinci olarak da bu alan içerisinde taşkından zarar görebilecek tarım alanlarında yayılım gösteren farklı toprakların temel karakteristiklerini belirleyerek detaylı toprak haritasının oluşturulması amaçlanmıştır. Farklı topografik özelliklere (düz, dalgalı, tepelik) sahip olan alan içerisinde özellikle düz ve düze yakın fizyografya hâkim durumdadır. Deniz seviyesinden yükseklik ortalama $1 \mathrm{~m}$ ile $47 \mathrm{~m}$ arasında değişmektedir. Yıllık ortalama yağış ve sıcaklık durumu ise sırasıyla $964.3 \mathrm{~mm}$ ve $14.3{ }^{\circ} \mathrm{C}$ 'dir. Arazi gözlemleri ve topografik, jeolojik ve arazi kullanım durumlarının incelenmesinden sonra, 17 toprak profil çukuru kazılmıştır. Her bir profilden genetik horizon esasına göre toprak örnekleri alınmış ve laboratuvarda analizleri yapılmıştır. Laboratuvar analiz sonuçları ve toprak taksonomisine göre topraklar tanımlanmış ve sınıflandırılmıştır. Topraklar 4 ordo, 6 altordo, 8 büyük grup ve 10 alt grup içerisine yerleştirilmiştir. Bu ordolar içerisinde \% 55.3 ile Inceptisoller en fazla alan kaplarken bunu sirasıyla \% 30.6 ile Entisoller, 8.9\% ile Vertisoller ve \% 5.2 ile de Alfisoller izlemektedir. 10 toprak serisi ve bunlara ait sınırlar 1:25.000 ölçekli harita üzerine aktarılmıştır. Araştırma alanı içerisinde Mescitli serisi (\% 2.3) en küçük alana sahip iken, Altunlu serisi (\% 17.1) en fazla yayılım alanına sahiptir. Buna ilaveten araştırma alanında belirlenen bazı toprak sorunları hakkında da önerilerde bulunulmuştur.
\end{abstract}

Anahtar Kelimeler: Toprak etüt ve haritalama, toprak sınıflama, Terme Çayı

\section{Determination of Some Basic Physiographic Characteristics and Soil Mapping for Flood Lands}

\begin{abstract}
The main aims of this study were to determine firstly land use-land cover, topographic and soil characteristics in $53.6 \mathrm{~km}^{2}$ mostly flat land which was sized about $19 \mathrm{~km}$ length which is between Black Sea and at the beginning of mountain and $2.5 \mathrm{~km}$ width in both sides of Terme River that located on east part of Çarşamba Plain and secondly, in order to generate detailed soil map by determining basic characteristic of different soils formed in arable land which can be damaged from flooding events. Different physiographic units (mostly flat, rolling and hilly) are particularly common in the study area. Elevation varies from $1 \mathrm{~m}$ to $47 \mathrm{~m}$ above sea level. Average annual precipitation and temperature are $964.3 \mathrm{~mm}$ and $14.3{ }^{\circ} \mathrm{C}$, respectively. After examination of topographic, land use, geologic and geomorphologic maps and land observation, 17 profile places were excavated in the study area. The soil samples were taken from each profile based on genetic horizon sand their analyses were done in the laboratory. According to the results of laboratory analyses by taking into consideration of soil taxonomy, these soils were classified and described. The soils were grouped under 4 order, 6 suborder, 8 great groups and 10 subgroups within 10 soil series and soil boundaries were shown on the 1:25.000 scale map. Inceptisol has the highest land which is about $55.3 \%$ of the total area following by Entisol (30.6\%), Vertisol (8.9\%) and Alfisol (5.2\%) in the study area. Whereas Mescitli series has the largest area (2.3\%), Altunlu series has the smallest area in the study area (17.1\%). In addition, some necessary recommendations were given to solve some soil problems in this study.
\end{abstract}

Keywords: Soil survey and mapping, soil classification, Terme River 


\section{Giriş}

Birçoğu gelişmekte olan veya gelişmemiş ülkelerde bulunan doğal kaynaklar; yanlış ve plansız arazi kullanımı, nüfustaki hızlı artış, duyarlı ekosistemlerdeki toprak erozyonu, kıt kaynaklara yönelik çok yönlü talepler, fakir kırsal nüfus, kurumsal desteklerin yetersizliği veya olmayışı vb. nedenler ile baskı altında bulunmaktadır (Yılmaz, 2005). Bu durum dünya doğal kaynak yönetiminde bütünsel havza yönetimi kavramını ortaya çıkarmıştır. Bütünsel havza yönetimi, doğal kaynaklarla birlikte havzada yaşayan halkın sosyo-ekonomik yapısını, havzanın hidrolojik özelliklerini, iklim, toprak ve bitki varlığını ortaya koymayı gerektirmektedir. En önemli doğal varlık olan toprak ve arazilerin korunmasını, dengeli kullanılmasını ve geliştirilmesini amaçlayan girişimler; ancak toprak ve arazinin sahip olduğu değerlerin, gelişen bilim ve teknolojinin olanaklarını da kullanarak detaylı tanımlanması, özelliklerinin çok iyi bilinmesi, buna dayalı planların yapılması ile mümkün olacaktır. Arazi kaynaklarının doğru ve sürdürülebilir kullanımını sağlamak amacıyla başvurulan en önemli kaynaklardan biriside, farklı özelliklere sahip toprakların yayılımlarını gösteren toprak haritalarıdır. Toprak etüt ve haritalama çalışmaları sonucu üretilen toprak haritaları ve bununla ilişkili sunulan raporlar kullanıcılar için toprak veri tabanını oluşturmaktadır. Raporların doğruluğu, detay ve içerdiği ilave bilgilerin zenginliği, bu amaçla sonraki kullanımlar için geçerli sonuçlar alınmasını sağlamaktadır.

Tarımsal potansiyeli yüksek değere sahip araziler, nehirlerin zamanla biriktirmiş olduğu depozitler üzerinde oluşan alüviyal arazilerdir. Bu arazilerin tarımsal potansiyelleri yüksek olmasına karşılık, en önemli sorunlarından birisi de taşkın olaylarına maruz kalmalarıdır. Ülkemizde ve dünyada yaşanan nehir taşkınları ve seller, tarım arazilerinin zarar görmesine neden olduğu gibi, ciddi can ve mal kayıplarına da sebep olan doğal afetlerden biridir. Özellikle son yıllarda küresel ısınmadan kaynaklı zamansız taşkınlar, derelerin ıslah edilerek yapılaşmaya açılması ve taşkın koruma yapılarının yetersiz oluşu gibi sebepler doğabilecek zararların boyutunu arttırmaktadır. Dolayısıyla taşkın alanlarının tespiti sadece yerleşim alanları için değil aynı zamanda tarımsal faaliyetlerin yer aldığ $\breve{g}_{1}$ alanlardaki dağ ${ }_{1} l_{1}$ gösteren toprak özelliklerinin de bilinmesi gerekmektedir.

Ülkemizde 1938 sinıflandırma sistemine göre yapılmış mevcut toprak haritaları, gerek veri içeriği gerekse de doğruluk açısından günümüz koşullarına uygun değildir. Çünkü mevcut haritalar kullanılarak yapılan arazi çalışmalarında kontrol noktaları arasında mesafenin yaklaşık $1.5 \mathrm{~km}$ olması doğruluk derecesini oldukça düşürmekte ve böylece söz konusu haritalar özellikle detaylı arazi kullanım planlama çalışmalarında hizmet veremez duruma gelmektedir. Ayrıca, (Mülga) Toprak-Su Genel Müdürlüğü'nce 1965-1971 yılları arasında yapılan ve 1982-1984 yıllarında revize edilen 1:25.000 ölçekli yarı detaylı toprak haritalarında altlık harita olarak topografik haritaların kullanılmış olması nedeniyle, özellikle düz-düze yakın tarımsal potansiyeli yüksek olan alüviyal alanlarda ve delta ovalarında toprak sınırları sağlıklı olarak belirlenememiştir. Nitekim topografik haritalarda düz arazilerin özellikle de alüviyal arazilerde toprak sınırlarının belirlenip çizilmesinde referans olacak herhangi bir bilgi bulunmamaktadır (Dengiz ve ark., 2010).

Terme Çayı her yıl özellikle bahar aylarında yağış ve eriyen kar suları nedeniyle gerek Terme ilçesi yerleşim bölgesinde, gerekse de tarım alanlarında önemli sel taşkınlarına neden olmaktadır. Tarım arazilerine yönelik yaşanan taşkınlarda hangi bölgede ne kadarlık bir alanın zarar göreceğine dair bir bilgi yoktur. Dolayısıyla sel taşkını olabilecek alan içerisinde yer alan toprakların kalite ve karakteristik özellikleri ile bu topraklar üzerinde yetiştirilen ürünlere yönelik temel bir veri tabanı oluşturulması gerekmektedir. Elde edilen çıktılardan öncelikle çalışma bölgesindeki tarım arazisi sahibi çiftçiler ile ilgili tarımsal kuruluşlar faydalanacaktır. Buna paralel olarak, sonuç çıktıları çevre korumaya yönelik çalışma yapan gönüllü kuruluşlardan, bölgedeki su havzalarının rehabilitasyonu ile ilgili çalışma yapan birimlere kadar, birçok kuruma çok önemli temel veriler sağlayacaktır. Çalışmanın en önemli çıktılarından biri de, pek çok doğal afet ve hastalıkların tarım ve hayvancılıkta neden olduğu maddi zararların karşılanmasında hizmet veren Türkiye Tarım Sigortaları Sistemi (TARSIM) gibi kurumlara sel baskınlarına yönelik sigorta risk primlerinin doğru bir şekilde belirlenmesine katkı sağlamasıdır.

Yapılan bu çalışma ile Çarşamba Ovası'nın doğusunda kalan ve Terme Çayı'nın ovaya girdiği noktadan denize döküldüğü yere kadar olan yaklaşık 19 km'lik mesafe içerisinde ve akarsuyun her iki yakasında yine yaklaşık $2.5 \mathrm{~km}$ genişliğe sahip toplamda $53.6 \mathrm{~km}^{2}$ alan içerisinde; toprak, topografya, arazi kullanımı ve arazi örtüsü vb. karakteristiklerinin ortaya çıkartılması ve bu alan içerisinde taşkından zarar görebilecek tarım alanlarında yayılım gösteren farklı toprakların temel karakteristiklerini belirleyerek toprak haritasının oluşturulması amaçlanmıştır. 


\section{Materyal ve Yöntem}

\subsection{Materyal}

\subsubsection{Araştırma alanı genel özellikleri}

\subsubsection{Coğrafi konum}

Çalışma, Samsun ilinin Terme ilçesi sınırları içerisinde ve Çarşamba Ovası'nın doğusunda yer alan Terme Çayı'nın Çarşmaba Ovası'na girdiği yer ile denize döküldüğü yaklaşık $20 \mathrm{~km}$ mesafe ile çayın her iki yakası arasındaki $53.6 \mathrm{~km}^{2}$ genişlik kaplayan alan içerisinde gerçekleştirilmiştir. Samsun iline bağlı Orta Karadeniz Bölgesi'nde bulunan Terme ilçesi; yüzölçümü $583 \mathrm{~km}^{2}$ olup, Terme Çayı kenarında ve denizden $3 \mathrm{~km}$ içeride kurulmuştur (Şekil 1). İlçe ekonomisinin temel kaynağı tarım olup, toplam arazi varlığı 548570 dekardır. Bu arazilerin 426310 dekarı üzerinde tarımsal üretim yapılmakta olup, toplam arazi varlığının \% 77.71'ini oluşturmaktadır.

\subsubsection{Topografik özellik}

İlçe topografik bakımdan çok değişkenliğe sahip olup, 0-10 m yüksekliğe sahip delta ovasından 970 metreye kadar yüksekliğe çıkabilmektedir. İlçenin güneyinde yer alan Canik Dağları'nın yüksekliği yer yer 2000 metreyi bulmaktadır. Yüzölçümün yarısını oluşturan bu dağlık ve engebeli arazi findık bahçeleriyle kaplıdır. Kuzey Çarşamba Ovası'nın doğu ucu, ilçe sınırları içindedir. Yükseltisi 20-70 m arasında değişen ova, Terme Ovası adıyla da anılır. Ovanın güneyinde fazla yüksek olmayan tepeler görülür. Güneydeki dağlardan beslenen Terme Çayı, ilçe merkezini aştıktan sonra Karadeniz'e ulaşır. Çalışma alanının topografik özelliklerinin daha iyi anlaşılması ve yapılan çalışmalar için en önemli altlığ1 oluşturan topografik modelleri 1:25.000 ölçekli topografik haritalardan üretilen Sayısal Yükselti Modeli (SYM)'nden elde elde edilmiş ve eğim, yükselti ve kabartı haritaları oluşturulmuştur (Şekil 1 ve Şekil 2).

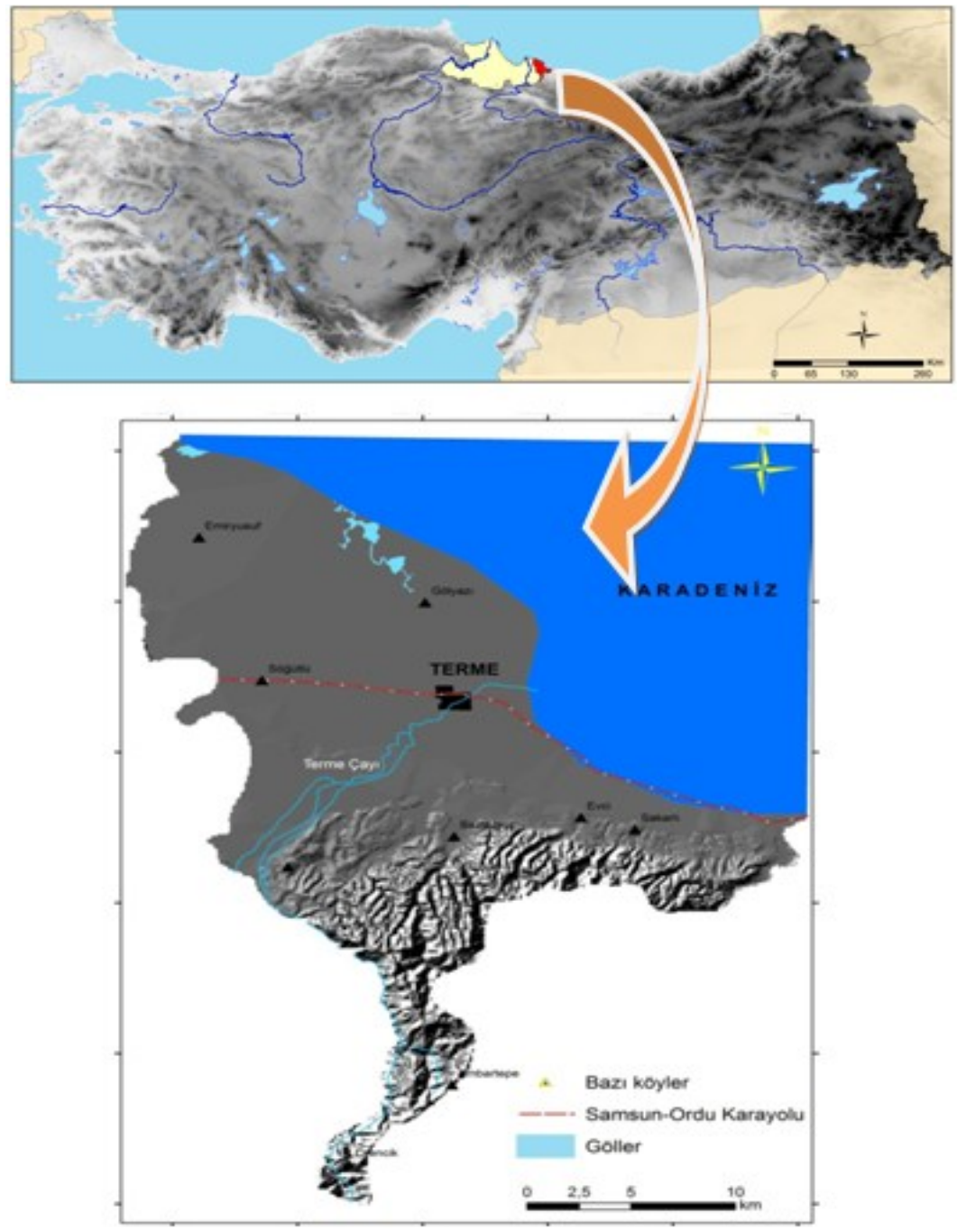

Şekil 1. Çalışma alanı lokasyon haritası 

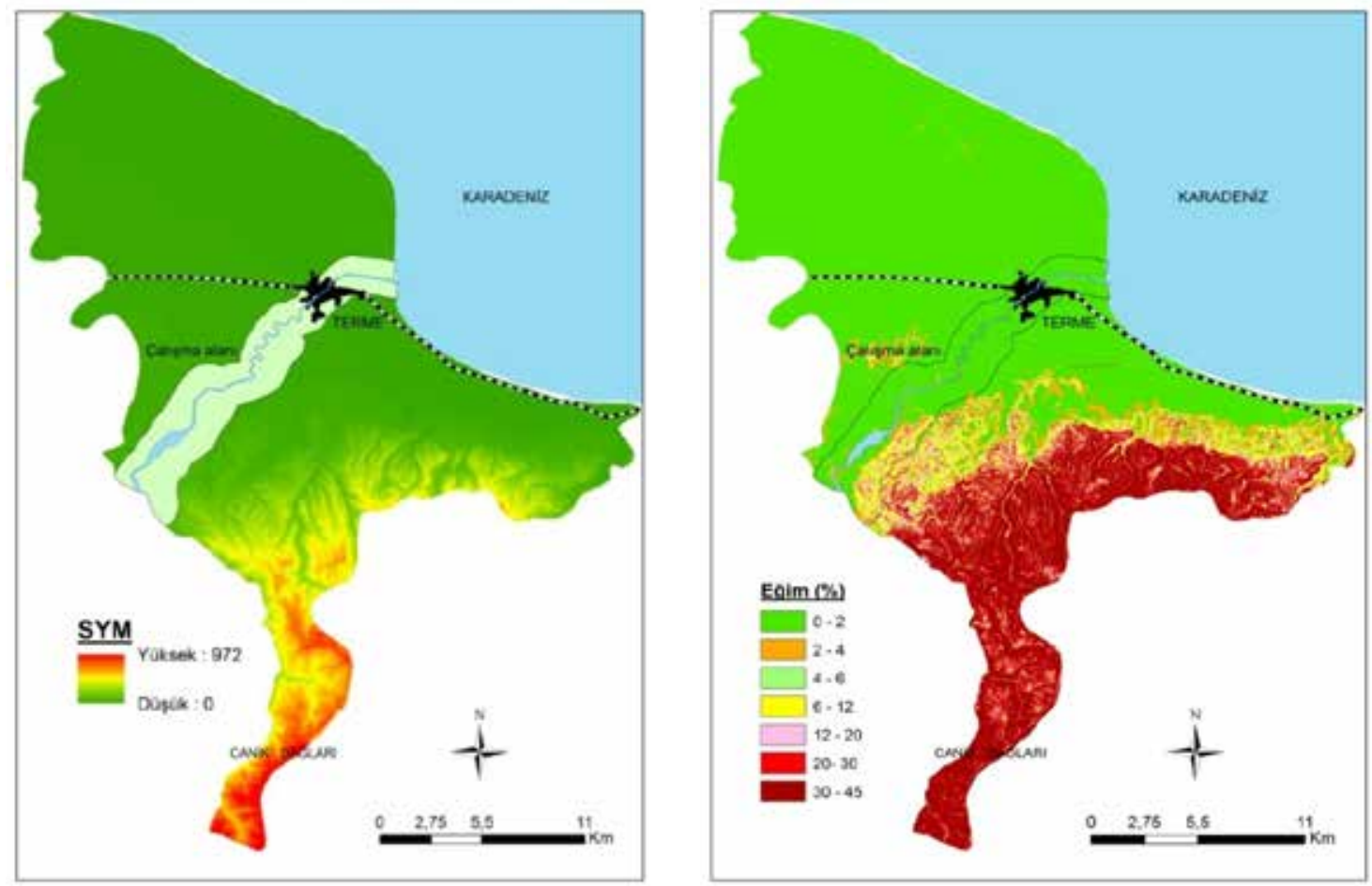

Şekil 2. Terme ilçesi sayısal yükselti ve eğim haritaları

Taşkın oluşmasında çok önemli bir etkiye sahip olan eğim faktörü, havzanın jeomorfolojik özellikleri içinde yer alır. Bütün koşullar aynı olduğunu varsaydığımızda, eğimin fazla olduğu yerlerde, toprağın su tutma kabiliyetinin az olması nedeniyle, yağışla gelen suların toprağa sızması eğimin az olduğu alanlara oranla daha azdır. Bunun sonucunda akışa geçen su miktarı eğimin fazla olduğu alanlarda daha fazla olur. $\mathrm{Bu}$ alanlarda bitki örtüsünün de çok büyük önemi vardır. Bitki örtüsünün az olduğu yerlerde akarsuyun taşıdığı sediment miktarı daha fazladır. $\mathrm{Bu}$ durum aynı zamanda alüviyal arazilerin oluşmasında önemli bir mekanizma olan taşınım ve sedimantasyon olaylarınıda etkileyerek, mesafe içerisinde farklı tane boyutundaki fraksiyonları içeren, gerek yataylamasına gerekse de dikeylemesine alan içerisinde birikimler olabilmektedir.

Terme Çayı, Terme ilçe merkezinin $5 \mathrm{~km}$ mansabında Karadeniz'e birleşmektedir. İlçenin ovalık alanlarında taban suyunun yüksek olması bitkisel üretimi engellemektedir. Özellikle yağışların yoğun olduğu dönemlerde ovalarda ve taban arazilerde oluşan göllenmeler, sel taşkınları bitki gelişimini ve verimi olumsuz etkilemesinin yanı sıra; dere kenarlarında bulunan verimli toprakların, nehrin kenar aşındırma ve koparmaları sonucu kayıp olmasına da neden olmaktadır.

\subsubsection{3. İklim}

Terme'de her mevsim yağışlı tipik Karadeniz iklimi hüküm sürmektedir. Terme ilçesine en yakın Ünye 17624 nolu rasatın 1960-2014 y1lları arası verilerine göre; yıllık ortalama yağış miktarı $964.8 \mathrm{~mm}$ olup, en fazla Kasım ayında en düşük ise $52.7 \mathrm{~mm}$ ile Mayıs ayında ölçülmüştür. İlçenin yıllık sicaklık ortalamas $14.3^{\circ} \mathrm{C}$ olup, en sicak ay $23.2^{\circ} \mathrm{C}$ ile Ağustos ve en düşük sıcaklık ise $6.8{ }^{\circ} \mathrm{C}$ ile Şubat ayında ölçülmüştür. Toprak taksonomisine göre ise toprak nem kontrol kesitinde $50 \mathrm{~cm}$ derinlikte toprak sıcaklığ $1{ }^{\circ} \mathrm{C}$ 'nin üzerinde olduğu dönemin yarısından daha fazlası kadar süre kuru değildir (aridic nem rejiminden farkl1). Ayrıca toprak nem kontrol kesiti kış gün dönümünden sonraki (21 Aralık) 5 ay içerisinde ardışık olarak 45 gün veya daha fazla nemli olması ve yaz gün dönümünden (21 Haziran) sonraki 4 ay içerisinde ardışık 45 gün kadar uzun süre kuru kalmaması (Xeric nem rejiminden farklı) nedeniyle toprak nem rejimi Ustic olarak belirlenmiştir. Araştırma alanının sıcaklık rejimi; y1llık ortalama toprak sicaklığ $18{ }^{\circ} \mathrm{C}$ 'den fazla, 15 ${ }^{\circ} \mathrm{C}$ 'den az ve $50 \mathrm{~cm}$ 'deki yıllık ortalama kış ayları toprak sıcaklığı ile yıllık ortalama yaz ayları toprak sıcaklığı arasındaki fark $6{ }^{\circ} \mathrm{C}$ 'den fazla olduğu için Mesic sicaklık rejimi olarak bulunmuştur (Anonymous, 1999). 


\subsubsection{Mevcut arazi kullanım ve arazi örtüsü}

Terme Çayı'nın her iki yakasının yaklaşık birer km mesafe alanı kaplayan çalışma alanı içerisinde yer alan mevcut arazi kullanım dağılımı Şekil 3'te verilmiştir. Alanda yaygın olarak findık yetiştiriciliği yer alırken, bunu diğer arazi kullanım türü olan kuru tarım izlemektedir. Ayrıca toplam alanın \% 11'ine karşılık gelen 5450.4 da alanda çeltik üretimi yapıldığı görülmektedir. \% 9.5'lik kısmı ise bataklık, gölet, su kanalı, kumul alan ve dere yatağından oluşmaktadır.

\subsection{2. Çalışmada kullanılan altlık materyal ve programlar}

Bu çalışmada, araștırma alanına ait SAMSUN $\mathrm{F} 37 \mathrm{c} 1$ ve $\mathrm{F} 37 \mathrm{c} 2$ paftası içerisine giren 1:25.000 ölçekli topografik harita temel kartografik materyal olarak kullanılmıştır. 1:25.000 ölçekli topografik haritalar sayısallaştırılmıştır. Topografik haritaların sayısallaştırılması, toprak veri tabanı ve sayısal toprak haritalarının oluşturulmasında TNT Mips 6v ve ArcGIS 9.3v coğrafi bilgi sistemi programları kullanılmıştır.

\subsection{Yöntem}

Akarsuların zamanla taşıdığı farklı depozitler üzerinde oluşmuş alüviyal topraklar kısa mesafeler içerisinde fiziksel, kimyasal, morfolojik yönden çok farklı özellikler göstermekte ve birbirinden farklı topraklar oluşabilmektedir. Alüviyal araziler üzerinde oluşmuş toprakların özelliklerinin belirlenmesi ve toprak haritasının oluşturulması işlemi dört aşamada gerçekleştirilmiştir. Terme çayının taşkın olayları sonucu tarım arazileri üzerinde meydana getirdiği olumsuzluklara yönelik ova içerisinden denize döküldüğü yaklaşık $19 \mathrm{~km}$ mesafe uzaklıkta ve akarsuyun her iki yakasının $1000 \mathrm{~m}$ mesafede kalan alüviyal sediment üzerinde oluşmuş topraklar incelemeye alınmıştır.

İlk aşama olarak topografik harita, jeoloji ve jeomorfolojik özellikler ile bölgeye ait iklim verileri toplanmıştır. Belirlenen bitki deseni, arazi gözlemleri ve arazi kullanımının yanı sıra oluşturulan sayısal yükselti modeli kullanılarak alanda yayılım gösteren farklı fizyografik üniteler, rölyef, bakı ve arazi şekilleri (koluviyal etek

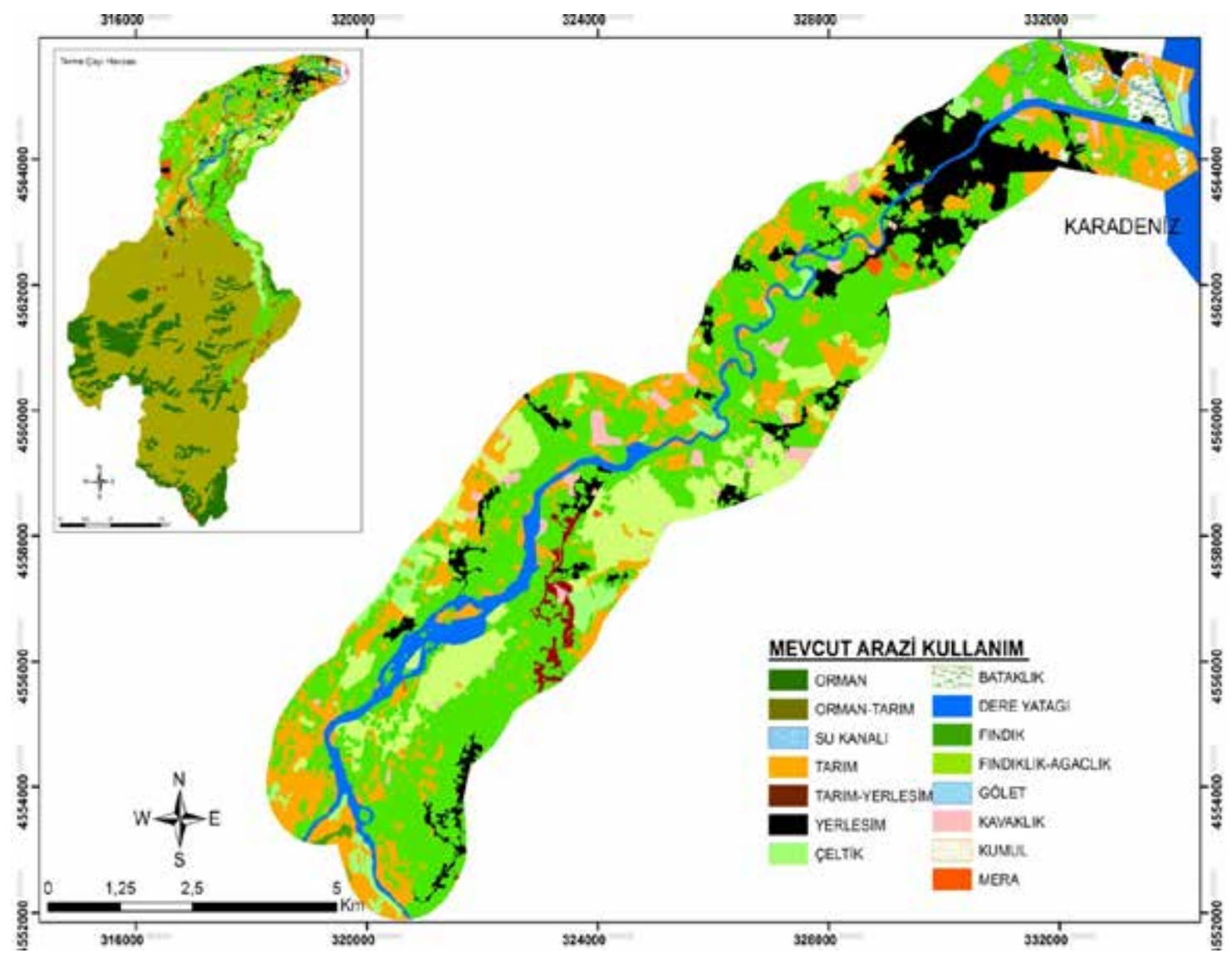

Şekil 3. Çalışma alanı mevcut arazi kulanım haritası 
araziler, teraslar, nehir bankları vb.) belirlenmiştir. Böylece belirlenen ana materyaldeki çeşitlilik ve farklı fizyografya üzerinde oluşmuş olası farklı topraklar tespit edilmiş ve ilk taslak toprak haritası oluşturulmuştur. İkinci aşama olan arazi çalışmasında ise daha önceden yapılan büro çalışması sonucu belirlenen farklı özellikteki toprak serileri üzerinde toprak profil yerlerinin koordinatları kaydedilmiş ve Yer Konumlama Cihazı (Global Positioning System, GPS) yardımı ile bu noktalara gidilerek profil çukurları açılmıştır. Çalışma alanında saptanan farklı toprak profilinden genetik horizon esasına göre toprak örnekleri alınmıştır. Arazide toprakların morfolojik özelliklerinin incelenmesi amacıyla dikkate alınan kriterler, örneklemeler ve sinıflandırma için Anonymous (1993, 1999) kullanılmıştır.

Alınan toprak örneklerinde bünye, Bouyoucous (1951)'a göre; hacim ağırlığı, Blake ve Hartge (1986)'a göre; tarla kapasitesi ve solma noktas1, Richards (1954)'a göre; yarayışlı su miktarı ise örneklerin tarla kapasitesi ve daimi solma noktaları arasındaki farktan hareketle hesap yolu ile belirlenmiştir. Ayrıca, katyon değişim kapasitesi ve değişebilir katyonlar, Rhoades (1982); kireç, Anonymous (1993); toprak reaksiyonu $(\mathrm{pH})$ ve elektriksel iletkenlik (EC), Anonymous (1992); organik madde, Jackson (1958) tarafindan bildirilen yöntemlere göre saptanmıştır.

Son aşamada ise; farklı özelliklere sahip toprakların analiz sonuçları da dikkate alınarak gerekli düzeltmeler yapılmış ve arazide $300 \mathrm{~m} \mathrm{x}$ $300 \mathrm{~m}$ aralıklarla oluşturulmuş grid yöntemi kullanılarak yapılan sondalama sonucu sınırları kesinleştirilerek, çalışma alanının 1:25.000 ölçekli temel toprak haritası yapılmıştır.

\section{Bulgular ve Tartışma}

\section{1. Çalışma alanı toprak serilerinin fiziksel, kimyasal ve bazı morfolojik özellikleri}

Çalışma alanında toplam 11 seri belirlenmiştir (Şekil 4). Seriler içerisinde \% 17.1 ile Altunlu Serisi en fazla yayılım alanına sahip iken, \% 2.3 ile Mescitli Serisi en az alanda dağılım göstermektedir. Serilere ait bazı kimyasal ve fiziksel analiz sonuçları ise Tablo 1 ve Tablo 2'de verilmiştir.

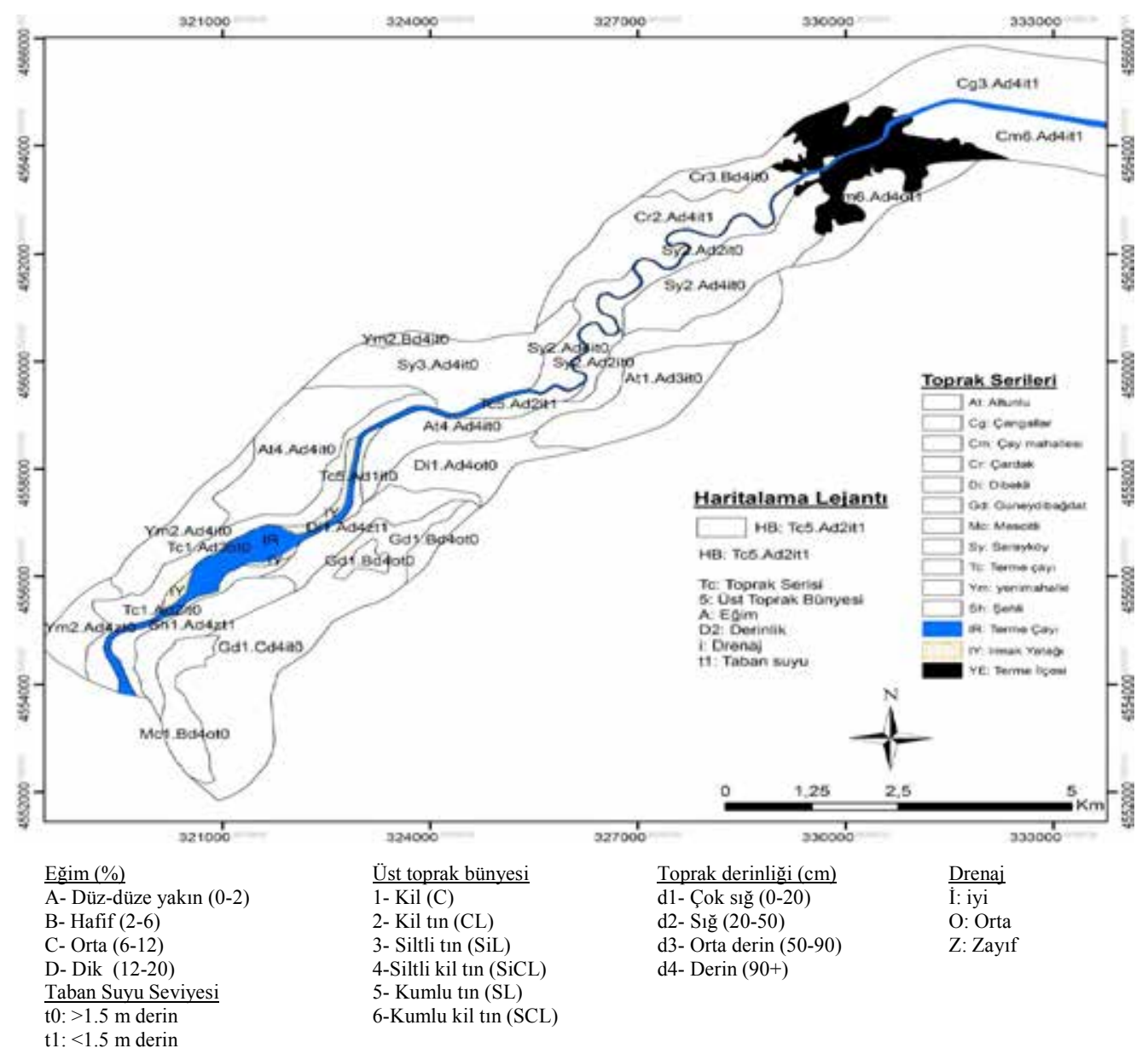

Şekil 4. Araştırma alanına ait temel toprak haritası 
Tablo 1. Araştırma alanı toprak serilerine ait kimyasal analiz sonuçları

\begin{tabular}{|c|c|c|c|c|c|c|c|c|c|}
\hline \multirow[t]{2}{*}{ Horizon } & \multirow{2}{*}{$\begin{array}{l}\text { Derinlik } \\
(\mathrm{cm})\end{array}$} & \multirow[t]{2}{*}{$\mathrm{pH}$} & \multirow{2}{*}{$\begin{array}{l}\text { Tuz } \\
(\%)\end{array}$} & \multirow{2}{*}{$\begin{array}{c}\text { Kireç } \\
(\%)\end{array}$} & \multirow{2}{*}{$\begin{array}{l}\mathrm{OM} \\
(\%)\end{array}$} & \multirow{2}{*}{$\begin{array}{c}\mathrm{KDK} \\
\left(\mathrm{cmol} \mathrm{kg}^{-1}\right)\end{array}$} & \multicolumn{3}{|c|}{ Değişebilir katyonlar $\left(\mathrm{cmol} \mathrm{kg}^{-1}\right)$} \\
\hline & & & & & & & $\mathrm{Na}^{+}$ & $\mathrm{K}^{+}$ & $\mathrm{Ca}^{++}+\mathrm{Mg}^{++}$ \\
\hline \multicolumn{10}{|c|}{ Mescitli serisi } \\
\hline A & $0-17$ & 6.20 & 0.05 & 0.30 & 3.20 & 41.20 & 0.18 & 0.49 & 40.52 \\
\hline Bw1 & $17-45$ & 7.16 & 0.05 & 0.40 & 1.86 & 47.45 & 0.38 & 0.41 & 46.66 \\
\hline Bw2 & $45-66$ & 7.86 & 0.11 & 3.20 & 2.61 & 58.32 & 0.51 & 0.45 & 57.36 \\
\hline $\mathrm{Bk}$ & $66-95$ & 8.02 & 0.07 & 17.45 & 0.76 & 42.99 & 0.41 & 0.40 & 42.18 \\
\hline $\mathrm{Ck}$ & $95+$ & 7.80 & 0.08 & 26.32 & 0.62 & 37.12 & 0.44 & 0.34 & 36.34 \\
\hline \multicolumn{10}{|c|}{ Terme Çayı serisi } \\
\hline $\mathrm{Ap}$ & $0-18$ & 5.42 & 0.02 & 0.10 & 5.66 & 26.52 & 0.21 & 0.20 & 26.11 \\
\hline $\mathrm{A} 2$ & $18-40$ & 5.65 & 0.02 & 0.10 & 3.81 & 23.97 & 0.17 & 0.15 & 23.65 \\
\hline $\mathrm{AC}$ & $40-65$ & 6.19 & 0.03 & 0.10 & 2.28 & 30.76 & 0.34 & 0.21 & 30.21 \\
\hline$\underline{\mathrm{C}}$ & 65 & - & - & - & - & - & - & - & - \\
\hline \multicolumn{10}{|c|}{ Şehli serisi } \\
\hline$\overline{\mathrm{A} 1}$ & $0-18$ & 7.36 & 0.08 & 1.40 & 4.47 & 51.68 & 0.18 & 0.99 & 50.51 \\
\hline A2 & $18-38$ & 7.76 & 0.08 & 0.80 & 2.61 & 45.05 & 0.18 & 0.60 & 44.27 \\
\hline Bss & $38-68$ & 7.04 & 0.07 & 0.30 & 2.09 & 47.28 & 0.21 & 0.43 & 46.64 \\
\hline $\mathrm{Cg}$ & $68+$ & 7.60 & 0.08 & 1.30 & 0.84 & 41.47 & 0.22 & 0.58 & 40.67 \\
\hline \multicolumn{10}{|c|}{ Güneydibağdat serisi } \\
\hline Ap & $0-23$ & 6.50 & 0.07 & 0.60 & 3.48 & 45.65 & 0.27 & 0.33 & 45.06 \\
\hline $\mathrm{Bw}$ & $23-48$ & 7.18 & 0.05 & 1.30 & 1.85 & 40.65 & 0.27 & 0.31 & 40.07 \\
\hline $\mathrm{BC}$ & $48-75$ & 7.14 & 0.06 & 4.30 & 1.44 & 44.51 & 0.68 & 0.30 & 43.53 \\
\hline $\mathrm{C} 1$ & $75-115$ & 8.06 & 0.08 & 5.79 & 0.48 & 51.85 & 1.36 & 0.39 & 50.10 \\
\hline $\mathrm{C} 2 \mathrm{k}$ & $115+$ & 8.26 & 0.06 & 34.89 & 0.08 & 32.45 & 1.26 & 0.20 & 30.99 \\
\hline \multicolumn{10}{|c|}{ Dibekli serisi } \\
\hline$\overline{\mathrm{Ap}}$ & $0-21$ & 7.54 & 0.05 & 3.69 & 3.58 & 35.92 & 0.16 & 0.46 & 35.30 \\
\hline $\mathrm{A} 2$ & $21-42$ & 7.85 & 0.04 & 4.98 & 2.32 & 32.61 & 0.21 & 0.33 & 32.07 \\
\hline Bss1 & $42-77$ & 7.81 & 0.05 & 1.50 & 1.75 & 47.01 & 0.21 & 0.38 & 46.42 \\
\hline Bss2 & $77-118$ & 7.65 & 0.08 & 1.40 & 0.56 & 44.73 & 0.23 & 0.51 & 43.99 \\
\hline $\mathrm{Cg}$ & $118+$ & 7.25 & 0.06 & 1.30 & 0.92 & 47.07 & 0.26 & 0.56 & 46.25 \\
\hline \multicolumn{10}{|c|}{ Sarayköy serisi } \\
\hline$\overline{\mathrm{Ap}}$ & $0-13$ & 6.20 & 0.04 & 0.40 & 5.75 & 46.63 & 0.31 & 0.22 & 46.10 \\
\hline $\mathrm{Bw}_{1}$ & $13-40$ & 6.58 & 0.06 & 0.30 & 2.77 & 55.33 & 0.24 & 3.46 & 51.63 \\
\hline $\mathrm{Bw}_{2}$ & $40-89$ & 6.83 & 0.04 & 0.40 & 1.27 & 48.37 & 0.28 & 0.91 & 47.18 \\
\hline$\underline{\mathrm{C}}$ & $89+$ & 7.14 & 0.02 & 0.80 & 0.63 & 40.05 & 0.40 & 0.42 & 39.24 \\
\hline & & & & & lu ser & & & & \\
\hline$\overline{\mathrm{A} 1}$ & $0-23$ & 6.88 & 0.04 & 0.30 & 4.77 & 40.49 & 0.33 & 0.17 & 39.99 \\
\hline $\mathrm{A} 2$ & $23-63$ & 7.39 & 0.01 & 0.40 & 1.54 & 18.42 & 0.40 & 0.06 & 17.97 \\
\hline $\mathrm{C} 1 \mathrm{~g}$ & $63-82$ & 7.40 & 0.05 & 0.30 & 2.45 & 24.02 & 0.39 & 0.12 & 23.51 \\
\hline $\mathrm{C} 2$ & $82-103$ & 7.28 & 0.02 & 0.30 & 2.61 & 36.25 & 0.23 & 0.61 & 35.41 \\
\hline $\mathrm{C} 3$ & $103-113$ & 7.12 & 0.02 & 0.20 & 0.75 & 14.95 & 0.39 & 0.11 & 14.45 \\
\hline & & & & & lar ser & & & & \\
\hline$\overline{\mathrm{A}}$ & $0-20$ & 7.37 & 0.08 & 0.50 & 3.20 & 24.46 & 1.72 & 0.29 & 22.45 \\
\hline $\mathrm{C} 1$ & $20-60$ & 7.54 & 0.00 & 0.10 & 3.88 & 21.85 & 1.32 & 0.15 & 20.38 \\
\hline $\mathrm{C} 2 \mathrm{~g}$ & $60-90$ & 7.31 & 0.09 & 0.30 & 2.38 & 14.29 & 0.81 & 0.46 & 13.02 \\
\hline C3g & $90+$ & 7.21 & 0.05 & 7.28 & 1.11 & 8.91 & 0.44 & 0.50 & 7.97 \\
\hline & & & & & ak seri & & & & \\
\hline $\mathrm{Ap}$ & $0-24$ & 6.35 & 0.05 & 0.50 & 3.25 & 42.99 & 0.30 & 0.28 & 42.40 \\
\hline Bw1 & $24-51$ & 6.67 & 0.05 & 0.40 & 2.84 & 51.14 & 0.35 & 0.18 & 50.61 \\
\hline Bw2 & $51-81$ & 7.47 & 0.05 & 2.49 & 2.11 & 43.59 & 0.47 & 0.17 & 42.95 \\
\hline $\mathrm{Cg}$ & $81+$ & 7.02 & 0.04 & 1.30 & 1.07 & 32.45 & 0.51 & 0.11 & 31.83 \\
\hline & & & & Yen & halle s & & & & \\
\hline$\overline{A p}$ & $0-25$ & 6.32 & 0.02 & 0.01 & 4.49 & 32.07 & 0.21 & 0.71 & 31.15 \\
\hline E & $25-42$ & 6.30 & 0.01 & 0.00 & 3.70 & 35.33 & 0.22 & 0.20 & 34.90 \\
\hline Bt1 & $42-57$ & 5.58 & 0.14 & 0.00 & 2.87 & 30.54 & 0.41 & 0.34 & 29.80 \\
\hline Bt2 & $57+$ & 5.47 & 0.01 & 0.00 & 1.01 & 33.15 & 0.67 & 0.36 & 32.13 \\
\hline & & & & Çay & allesi & & & & \\
\hline$\overline{\mathrm{Ap}}$ & $0-24$ & 6.10 & 0.04 & 0.40 & 4.74 & 36.58 & 0.37 & 0.19 & 36.02 \\
\hline Bw1 & $24-70$ & 6.70 & 0.02 & 0.50 & 2.54 & 41.09 & 0.32 & 0.24 & 40.53 \\
\hline Bw2 & $40-105$ & 6.95 & 0.03 & 1.40 & 1.59 & 38.21 & 0.36 & 0.23 & 37.61 \\
\hline $\mathrm{C}$ & $105+$ & 6.63 & 0.02 & 1.20 & 0.08 & 37.12 & 0.42 & 0.13 & 36.57 \\
\hline
\end{tabular}


Tablo 2. Araştırma alanı toprak serilerine ait fiziksel analiz sonuçları

\begin{tabular}{|c|c|c|c|c|c|c|c|c|c|}
\hline \multirow[t]{2}{*}{ Horizon } & \multirow{2}{*}{$\begin{array}{c}\begin{array}{c}\text { Derinlik } \\
(\mathrm{cm})\end{array}\end{array}$} & \multicolumn{4}{|c|}{ Bünye (\%) } & \multirow{2}{*}{$\begin{array}{l}\text { Hacim } \\
\text { ağırlığ1 } \\
\left(\mathrm{g} \mathrm{cm}^{-3}\right)\end{array}$} & \multirow{2}{*}{$\begin{array}{c}\text { Tarla } \\
\text { kapasitesi } \\
(\%)\end{array}$} & \multirow{2}{*}{$\begin{array}{c}\text { Solma } \\
\text { noktas1 } \\
(\%)\end{array}$} & \multirow{2}{*}{$\begin{array}{c}\text { Yarayışl } \\
\text { su } \\
(\%)\end{array}$} \\
\hline & & Kil & Silt & Kum & Sinif & & & & \\
\hline \multicolumn{10}{|c|}{ Mescitli serisi } \\
\hline $\bar{A}$ & $0-17$ & 53 & 30 & 17 & $\mathrm{C}$ & 1.19 & 44.5 & 33.6 & 10.9 \\
\hline Bw1 & $17-45$ & 39 & 40 & 21 & $\mathrm{CL}$ & 1.17 & 47.4 & 30.5 & 16.9 \\
\hline Bw2 & $45-66$ & 76 & 18 & 7 & $\mathrm{C}$ & 1.20 & 48.4 & 37.8 & 10.8 \\
\hline $\mathrm{Bk}$ & $66-95$ & 74 & 12 & 13 & $\mathrm{C}$ & 1.35 & 43.3 & 34.4 & 8.9 \\
\hline $\mathrm{Ck}$ & $95+$ & 82 & 15 & 3 & $\mathrm{C}$ & 1.36 & 45.2 & 34.6 & 9.6 \\
\hline \multicolumn{10}{|c|}{ Terme Çayı serisi } \\
\hline$\overline{\mathrm{Ap}}$ & $0-18$ & 42 & 33 & 24 & $\mathrm{C}$ & 1.45 & 33.9 & 23.2 & 10.7 \\
\hline A2 & $18-40$ & 36 & 37 & 27 & $\mathrm{CL}$ & 1.48 & 33.8 & 20.3 & 13.5 \\
\hline $\mathrm{AC}$ & $40-65$ & 46 & 26 & 29 & $\mathrm{C}$ & 1.32 & 38.6 & 23.7 & 14.9 \\
\hline $\mathrm{C}$ & 65 & - & - & - & - & - & - & - & - \\
\hline \multicolumn{10}{|c|}{ Şehli serisi } \\
\hline$\overline{\mathrm{A} 1}$ & $0-18$ & 63 & 28 & 9 & $\mathrm{C}$ & 1.11 & 45.5 & 35.1 & 10.4 \\
\hline A2 & $18-38$ & 69 & 23 & 8 & $\mathrm{C}$ & 1.34 & 44.8 & 32.1 & 12.7 \\
\hline Bss & $38-68$ & 71 & 22 & 7 & $\mathrm{C}$ & 1.23 & 47.6 & 37.1 & 10.5 \\
\hline $\mathrm{Cg}$ & $68+$ & 67 & 18 & 15 & $\mathrm{C}$ & 1.24 & 49.2 & 37.0 & 12.2 \\
\hline \multicolumn{10}{|c|}{ Güneydibağdat serisi } \\
\hline$\overline{\mathrm{Ap}}$ & $0-23$ & 45 & 36 & 19 & $\mathrm{C}$ & 1.34 & 44.1 & 25.4 & 18.7 \\
\hline $\mathrm{Bw}$ & $23-48$ & 35 & 40 & 26 & $\mathrm{CL}$ & 1.22 & 45.5 & 35.9 & 9.6 \\
\hline $\mathrm{BC}$ & $48-75$ & 70 & 23 & 7 & $\mathrm{C}$ & 1.21 & 44.5 & 36.2 & 8.3 \\
\hline $\mathrm{C} 1$ & $75-115$ & 80 & 13 & 7 & $\mathrm{C}$ & 1.11 & 50.3 & 37.8 & 12.5 \\
\hline $\mathrm{C} 2 \mathrm{k}$ & $115+$ & 86 & 13 & 2 & $\mathrm{C}$ & 1.28 & 45.6 & 36.3 & 9.3 \\
\hline \multicolumn{10}{|c|}{ Dibekli serisi } \\
\hline$\overline{\mathrm{Ap}}$ & $0-21$ & 49 & 28 & 24 & $\mathrm{C}$ & 1.42 & 39.7 & 31.0 & 8.7 \\
\hline A2 & $21-42$ & 43 & 25 & 32 & $\mathrm{C}$ & 1.34 & 35.4 & 26.3 & 9.1 \\
\hline Bss1 & $42-77$ & 57 & 23 & 20 & $\mathrm{C}$ & 1.20 & 44.2 & 36.5 & 7.7 \\
\hline Bss2 & $77-118$ & 55 & 26 & 19 & $\mathrm{C}$ & 1.13 & 48.9 & 35.9 & 13.0 \\
\hline $\mathrm{Cg}$ & $118+$ & 69 & 20 & 12 & $\mathrm{C}$ & 1.20 & 48.0 & 37.6 & 10.4 \\
\hline \multicolumn{10}{|c|}{ Sarayköy serisi } \\
\hline$\overline{\mathrm{Ap}}$ & $0-13$ & 38 & 36 & 26 & $\mathrm{CL}$ & 1.27 & 42.6 & 30.2 & 12.4 \\
\hline Bw1 & $13-40$ & 33 & 38 & 29 & $\mathrm{CL}$ & 1.53 & 40.4 & 29.1 & 11.3 \\
\hline Bw2 & $40-89$ & 23 & 53 & 24 & $\mathrm{~L}$ & 1.22 & 39.5 & 25.0 & 14.3 \\
\hline $\mathrm{C}$ & $89+$ & 26 & 27 & 46 & $\mathrm{~L}$ & 1.36 & 31.4 & 19.4 & 12.0 \\
\hline \multicolumn{10}{|c|}{ Altunlu serisi } \\
\hline$\overline{\mathrm{A} 1}$ & $0-23$ & 50 & 31 & 19 & $\mathrm{C}$ & 1.07 & 41.8 & 30.1 & 11.7 \\
\hline A2 & $23-63$ & 15 & 13 & 72 & SL & 1.30 & 14.1 & 11.4 & 3.7 \\
\hline $\mathrm{C} 1 \mathrm{~g}$ & $63-82$ & 12 & 53 & 35 & $\mathrm{SiL}$ & 1.42 & 15.4 & 10.3 & 5.1 \\
\hline $\mathrm{C} 2$ & $82-103$ & 24 & 29 & 47 & $\mathrm{~L}$ & 1.33 & 29.3 & 22.5 & 6.7 \\
\hline $\mathrm{C} 3$ & $103-113$ & 17 & 26 & 57 & SL & 1.48 & 19.4 & 13.8 & 5.6 \\
\hline & & & & & galar s & & & & \\
\hline$\overline{\mathrm{Ap}}$ & $0-24$ & 14 & 58 & 28 & SiL & 1.40 & 29.4 & 20.2 & 9.2 \\
\hline Bw1 & $24-51$ & 27 & 49 & 24 & $\mathrm{CL}$ & 1.34 & 38.9 & 28.7 & 10.2 \\
\hline Bw2 & $51-81$ & 9 & 42 & 48 & $\mathrm{~L}$ & 1.56 & 10.7 & 6.5 & 4.2 \\
\hline $\mathrm{Cg}$ & $81+$ & 9 & 8 & 83 & LS & 1.59 & 11.9 & 7.5 & 4.3 \\
\hline & & & & & rdak se & & & & \\
\hline$\overline{\mathrm{Ap}}$ & $0-24$ & 21 & 59 & 21 & $\mathrm{SiL}$ & 1.30 & 23.7 & 15.1 & 8.6 \\
\hline Bw1 & $24-51$ & 40 & 45 & 15 & $\mathrm{SiCL}$ & 1.25 & 41.2 & 33.6 & 7.6 \\
\hline Bw2 & $51-81$ & 35 & 44 & 21 & $\mathrm{CL}$ & 1.22 & 41.8 & 29.9 & 11.9 \\
\hline $\mathrm{Cg}$ & $81+$ & 27 & 27 & 46 & SCL & 1.29 & 33.0 & 22.2 & 10.8 \\
\hline & & & & & nahalle & & & & \\
\hline$\overline{\mathrm{Ap}}$ & $0-25$ & 29 & 31 & 40 & $\mathrm{CL}$ & 1.33 & 32.9 & 20.0 & 12.9 \\
\hline E & $25-42$ & 34 & 41 & 25 & $\mathrm{CL}$ & 1.56 & 32.6 & 20.0 & 12.6 \\
\hline Bt1 & $42-57$ & 64 & 23 & 13 & $\mathrm{C}$ & 1.40 & 37.6 & 26.0 & 11.6 \\
\hline Bt2 & $57+$ & 59 & 20 & 21 & $\mathrm{C}$ & 1.42 & 42.5 & 35.2 & 7.3 \\
\hline & & & & & ahalles & risi & & & \\
\hline$\overline{\mathrm{Ap}}$ & $0-24$ & 33 & 22 & 45 & SCL & 1.47 & 30.5 & 24.3 & 6.2 \\
\hline Bw1 & $24-70$ & 21 & 43 & 36 & $\mathrm{~L}$ & 1.19 & 34.7 & 22.8 & 11.9 \\
\hline Bw2 & $40-105$ & 33 & 48 & 19 & $\mathrm{CL}$ & 1.10 & 37.5 & 23.2 & 14.3 \\
\hline $\mathrm{C}$ & $105+$ & 28 & 25 & 46 & SCL & 1.46 & 26.7 & 16.6 & 10.1 \\
\hline
\end{tabular}


Mescitli serisi, yumuşak, bozuşmaya uğramış marn ana materyal üzerinde oluşmuş, derin ve zayıf drenajlı topraklardır. 125.3 ha yayılım alanı ile çalışma alanın en küçük dağglım alanına sahip serisi olup, toplam alanın $\% \quad 2.3$ 'ünü oluşturmaktadır. Yaklaşık \% 6-12 arasında olan orta eğime sahiptirler. Toprakların tuzluluk ve erozyon problemleri yoktur. Bünye yüzeyde kil iken, kil miktarı 17-45 cm'ler arasında kil tına dönüşmesine karşın bu derinlik sonrası kil miktarı artarak tekrar ağır bünyeli yapıya dönüşmektedir. Bünyedeki bu değișim katyon değişim kapasitesi (KDK) ve yarayışlı su tutma kapasitelerini de bir etkileyerek artışa neden olmakta ve sırasıyla 41.20-58.32 $\mathrm{cmol} \mathrm{kg}^{-1}$ ile \% 8.9-16.9 arasinda değişmektedir. Topraklar kireç oranı yüzey ve yüzey altı yaklaşık 60 cm'ye kadar çok az olmasına karşın, ana materyale yaklaştıkça çok kireçli olmaktadır. Bu durumun toprak rengine de yansıması görülmektedir. Toprakların profil boyunca ana spektral renkleri $2.5 \mathrm{Y}$ olmasina karşın, yüzey topraklarında value ve chroma değerleri düşük iken kalsik horizona doğru gidildikçe renk açılmakta, value ve chroma artmaktadır. Yağışın etkisi ile bu topraklarda kireç yıkanım olayı belirgin görülmektedir. Yüzeyde $\mathrm{pH}$ değeri bazik katyonların bir miktar topraktan uzaklaşması ile hafif asit reaksiyonlu olmasına karşın, derinlerde özelliklede ana materyalin etkisi ile bu oran hafif alkali reaksiyona dönüşmektedir. Toprakların pH değerleri 6.20 ile 8.02 arasında değişmektedir. Organik madde içeriği yüzey toprağında iyi düzeylerde (\% 3.20) iken, bu oran derinlere doğru azalma göstermektedir (Tablo 1 ve Tablo 2).

Terme Çayı serisi, Terme Çayı'nın taşkın zamanlarında biriktirmiş olduğu iri çakıllı alüviyal depozit özellikli ana materyalli, genç teraslar üzerinde oluşmuş topraklardır. Genellikle mera, çeltik, fındık ve kavaklık olarak kullanılmaktadır.

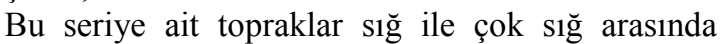
değişen derinlikte ve orta ve iyi drenajlı topraklardır. Seri toprakları 336.8 ha yayılımla toplam alanın \% 6.3'ünü oluşturmaktadır. \% 0-2 eğime sahiptirler. Bünye profil içerisinde değişkenlik gösterip yüzeyde kil iken, derinlik içerisinde kil tın olmaktadır. Bünyedeki bu değişim KDK ve yarayışlı su tutma kapasitelerini de etkileyerek azalmalarına neden olmakta ve sirasiyla 23.97-30.76 $\mathrm{cmol} \mathrm{kg}^{-1}$ ile \% 10.7-14.90 arasında değișmektedir. Topraklar kireçsiz veya çok az kireçli, organik madde ise yüzey toprağında \% 5.66 iken, bu oran derinlere doğru azalma göstermektedir. Toprakların profil boyunca ana spektral renkleri 2.5 Y'dir. Fakat organik maddenin yüksek olduğu alanlarda ise value ve chroma değerleri çok düşük olup, koyu renklidir.
Toprakların sığlaștığı yerlerde özellikle kum miktarındaki artış ile hacim ağırlıkları da artış göstermektedir. Toprak reaksiyonları hafif asit reaksiyonludur. Toprakların tuzluluk ve erozyon problemleri yoktur (Tablo 1 ve Tablo 2).

Killi ko-alüviyal birikinti üzerinde oluşmuş olan Şehli serisinin yüzey altı katmanlarında küçük yoğun kayma yüzeyleri mevcuttur. Şehli serisi 153.9 ha alan ile toplam alanın \% 2.9'unu oluşturmaktadır. $\mathrm{Bu}$ seri toprakları genellikle kavaklık, çeltik ve findık yetiştiriciliğinde kullanılmaktadır. Topraklar \% $\quad 0-2$ eğime sahip olup, doğuya doğru eğim artış göstermektedir. Seri toprakları derin ve zayıf drenajlı topraklardır. Toprakların tuzluluk ve erozyon problemleri yoktur. Bünyedeki tane dağılım oranı profil içerisinde hemen hemen aynı olup, sınıf ise kildir ve oranı \% 63-71 arasında değişmektedir. Toprakların bulundukları alanlar çukur-etek topografik pozisyon nedeniyle yüzey suların biriktiği alanlar olması ve zayıf drenaj özellikleri nedeniyle $80 \mathrm{~cm}$ 'den sonra indirgen özellikler olan gleyleşme-renk benekleri görülmüştür. Yüzeydeki granüler strüktür dişında profil içerisinde her hangi bir strüktüral gelişme belirlenememiştir. Yüzeyde topraklar yaklaşık \% 1.4 ile az kireçli iken, bu oran yıkanma sonucu azalarak derinlerde \% 0.3 'e inmektedir. Tüm profil hafif alkalin karakterli olup, tuzluluk problemleri yoktur. Toprakların hacim ağırlıkları toprakların killi olmaları nedeniyle hacim ağırlık değerleri düşük olmasına karşın, özellikle yüzey altı horizon özellikle toprak işleme sonucu bir miktar sıkışma ile yükselme göstermiştir. Toprakların hacim ağırlık değerleri 1.11 ile $1.34 \mathrm{~g} \mathrm{~cm}^{-3}$ arasında değişmektedir. Organik madde yüzey toprağında çok iyi düzeylerde (\% 4.47) iken, bu oran derinlere doğru azalma göstermektedir. Toprakların profil boyunca ana spektral renkleri $2.5 \mathrm{Y}$ 'dir, value ve chroma değerlerinde çok fazla bir değişim yoktur (Tablo 1 ve Tablo 2).

Yumuşak marn ana materyal üzerinde oluşmuş olan Güneydibağdat serisi, toplam alan içerisinde 649.7 ha alan ile \% 12.1'lik alanı oluşturmaktadır. $\mathrm{Bu}$ seri toprakları \% 12-20 eğimli, dik arazilerden oluşmaktadır. Yüzeyde kil bünyeye sahip olan seri toprakları 23-48 cm'ler arası kil tın, bu derinlikten sonra tekrar kil miktarındaki artış ile killi bünyeye dönüşmektedir. Dolayısıyla artan kil ile ayrıca bu katta strüktüral bir değişimle beraber yarı köşeli blok yapılar oluşmaktadır. Toprakların drenaj özellikleri zayıf ile orta arasında değişmektedir. Topraklarda en önemli toprak yapan olaylar içerisinde strüktüral oluşumun yanı sıra, bazik katyonların ve kirecin yıkanmasıdır. Kireç toprakta $50 \mathrm{~cm}$ derinliğe kadar çok az seviyelerde $(<\% 2)$ bulunurken, bu derinlikten sonra özellikle ana 
materyal etkisiyle bu oran \% 35'lere çıkmaktadır. Toprakların $\mathrm{pH}$ değerleri özellikle bazik katyonlardaki yıkanmaya bağlı olarak yüzeyde hafif asit özellik gösterirken $(\mathrm{pH}=6.5)$, profil içerisinde bu özellik değişerek hafif alkalin olmaktadır $(\mathrm{pH}=8.2)$. Organik madde sadece yüzeyde \% 3.48 olarak tespit edilmiş, alt derinliklere doğru ise bu oran önemli ölçüde azalma göstermiştir. Tuzluluk problemleri bulunmamaktadır. Toprakların yüksek kil içermeleri sonucu fazla su tutma kapasiteleri olmalarına karşın yarayışıı su düzeyleri düşüktür (Tablo 1 ve Tablo 2).

Dibekli serisi; yamaç arazi pozisyonunda, kolluviyal kil depozitli ana materyal üzerinde oluşmuş, derin ve zayıf drenajlı topraklardır. Profil $\mathrm{Ap} / \mathrm{A}_{2} / \mathrm{Bss} 1 / \mathrm{Bss} 2 / \mathrm{Cg}$ şeklinde horizon dizilimi göstermektedir. Yüzey altı toprak oluşumu olayı olarak özellikle küçük bol olarak görülen kayma yüzeyleri (basınç kutanları) belirlenmiştir. $\mathrm{Bu}$ alanlardaki topraklarda da genç topraklara nazaran pedogenetik olayların etkisi biraz daha fazladır. Bu seri toprakları 321.3 ha yayılımla toplam alanın $\% 6.0$ oluşturmaktadır. Yayılım gösterdiği alanlar \% 0-2 eğime sahip düzlüklerdir. $42 \mathrm{~cm}$ 'ye kadar yüzey toprakları kireçli iken, derinlere doğru yıkanma ile beraber bu oran bir miktar azalmakta ve kireç \% 1.30 ile \% 4.98 arasında değişmektedir. Toprakların KDK'ları 32.61-47.07 $\mathrm{cmol} \mathrm{kg}^{-1}$ ve organik maddeleri yüzeyde \% $3.58 \mathrm{iken,} \mathrm{bu} \mathrm{oran}$ derinlerde $\%$ 0.56'lara düşmektedir. Tuzluluk problemleri bulunmamaktadır (Tablo 1 ve Tablo 2).

Sarayköy serisi; ince siltli ve kumlu alüviyal depozit üzerinde oluşmuş, derin ve iyi drenajl topraklardır. Bu seri toprakları genç entisol toprak serilerine göre daha ileri bir pedolojik süreç etkisinde daha fazla kaldığı belirlenmiştir. Özellikle Terme Çayı'nın etkisinden uzak kalmaları, profil içerisinde yapısal değişiklikler sonucu meydana gelen strüktürel gelime ile cambik horizonların varlığı belirlenmiştir. Topraklar genel olarak Ap/Bw/C şeklinde horizon dizilimine sahiptirler. Ayrıca topraklarda derinlik içerisindeki düzensiz organik madde dağılımı nedeniyle fluventic bir özelliğe sahip olduğu da belirlenmiştir. $\mathrm{Bu}$ seri 859.6 ha yayılım alanıyla toplam alanın en fazla ikinci yayılım alanına sahip olup, \% 16.0'ını oluşturmaktadır. Yayılım gösterdiği alanlarda genellikle düz düze yakın eğimli olup, eğim \% 0-2 arasında değişmektedir. Yüzeyde profil kil tın bünyeli iken, derinlere doğru kil birikimi azalarak tınlı bünyeli olmaktadır. Tüm genetik horizonlar çok az kireçli olup, \% 0.3 ile $\% 0.8$ arasında değişmektedir. Yüzey ve yüzey altı toprakların bünye sınıfları aynı olmasına karşın, yüzey topraklarında hacim ağrılıkları $1.27 \mathrm{~g} \mathrm{~cm}^{-3}$ olarak belirlenmesine karşın, yüzey altı topraklarında bu oran $1.53 \mathrm{~g} \mathrm{~cm}^{-3}$ 'e kadar çıkmaktadır. Bu durum özellikle alanda uygulanan yoğun tarla trafiği sonucu topraklarda taban taşı oluşumunun bir göstergesidir. Toprak reaksiyonları nötr ile nötre yakın hafif alkalin reaksiyonludur. Toprakların tuzluluk problemleri bulunmamaktadir (Tablo 1 ve Tablo 2).

Altunlu serisi; farklı tane boyutlarında üst üste dizilim gösteren alüviyal depozit katmanları üzerinde oluşmuş, orta derinlikte ve iyi drenajlı topraklardır. Bu seri 914.2 ha yayılım alanı ile toplam alanın \% 17.1'ini oluşturarak alanın en fazla yayılım alanına sahip serisini oluşturmaktadır. Çoğunlukla üzerinde fındık yetiştirilen bu topraklar düz düze yakın eğimlidir. Yüzey toprakları killi olmasına karşın, yaklaşık 20 cm sonra kum oranı ani artış göstererek kumlu tına dönüşmektedir. Bu katı altında yer alan katmanlar ise siltli tın, tın ve kumlu tın bünyeli katmanlardan oluşmaktadır. İlk $20 \mathrm{~cm}$ 'de yoğun bir kil olması geçirimi zayıflatırken, hemen alt katmanlarda çok kaba bünyeli olması suyun profil içerisinde kalmasında sıkıntı yaratmaktadır. Profilde bünye düzensiz dağılım göstermekte olup, bu durum organik madde de belirlenmiştir. Bünye ve organik madde profil içerisinde düzensiz dağılımlı olmaları, toprakların fluventic özellik içerdiğini göstermektedir. Gerek organik madde de gerekse de bünyedeki derinlik artışı ile düzensiz bir dağılım göstermesi toprakların KDK değerlerine de yansımaktadır. pH değerleri nötr ve hafif alkalin civarındadır. Topraklar kireçsiz olup, profil boyunca çok fazla değişkenlik göstermemektedir. Toprakların profil boyunca ana spektral renkleri 2.5 Y'dir. Toprakların tuzluluk ve erozyon problemleri yoktur (Tablo 1 ve Tablo 2).

Alüviyal ince kum depozitler üzerinde oluşmuş olan Çangalar serisi, toplam alan içerisinde 388.2 ha alan ile \% 7.2'lik kısmını oluşturmaktadır. $\mathrm{Bu}$ seri toprakları \% 0-2 eğimli, düz düze yakın arazilerden oluşmaktadır. $\mathrm{Bu}$ seri toprakları yılın uzun bir dönemi sürekli taban suyu yükselmesi altında olmaları ve taşkınlara maruz kalmaları nedeniyle yüzeyde göllenmeler, $20 \mathrm{~cm}$ 'den sonra yoğun gley katı içermektedirler. Yüzeyde bünye siltli tın iken, hemen yüzey altı katta kil oranı bir miktar artarak killi tına dönüşmektedir. $\mathrm{Bu}$ katın altında ise kil oranı çok düşük kumlu bir alüviyal depozit içermektedir. Bu durum toprağın hacim ağırlığı ve su tutma kapasitesi ile de paralellik göstermektedir. Organik madde yüzeyde \% 3.20 olarak tespit edilmiş, alt derinliklere doğru ise bu oran önemli ölçüde düzensiz değişimler göstermiştir. Tuzluluk problemleri bulunmamaktadır. Kireç $90 \mathrm{~cm}$ derinlik içerisinde hemen hemen homojen dağılım göstermekte olup, 
$\%$ 1'den az düzeydedir. Toprak reaksiyonları hafif alkalindir (Tablo 1 ve Tablo 2).

Çardak serisi; ince alüviyal depozit üzerinde oluşmuş, derin ve iyi drenajlı topraklardır. Bu seri 395.0 ha yayılım alanı ile toplam alanın \% 7.41'ini oluşturmaktadır. \% 0-2 eğim ile düz düze yakın arazilere sahiptirler. Toprakların en önemli sorunları yüksek taban suyu ve sel takın riski altında olmalarıdır. Bünyeleri tüm profil boyunca orta ile orta kaba bünyeli olup, yüzeyde siltli tın iken, alt katlarda siltli killi tın, kil tın ve kumlu tın olarak değişmektedir. Toprakların tuzluluk problemleri bulunmamaktadır. Yüzey toprakları hafif asit reaksiyonlu iken, alt katlara doğru hafif alkalin olmaktadır. Tüm profil az kireçli olup, \% 0.40-2.49 arasında değişmektedir. Toprakların KDK'ları \% $32.45-51.14 \mathrm{cmol} \mathrm{kg}^{-1}$ arasinda değişmekte ve organik maddeleri yüzeyde \% 3.25 iken, bu oran derinlerde \% 1.07'lere düşmektedir. Tuzluluk problemleri bulunmamaktadır (Tablo 1 ve Tablo 2).

Alüviyal kil depozitli ana materyalli yaşlı teraslar üzerine oluşmuş Yenimahalle serisi, alan içerisinde yer alan serileri içerisinde en ileri toprak oluşum sürecine sahip olup, toprak taksonomisine göre Typic Hapulstalf olarak sınıflandırılmıştır. Profil Ap/E/Bt1/Bt2 şeklinde horizon dizilimi göstermektedir. $\mathrm{Bu}$ seri toprakları toplam alan içerisinde 280.5 ha alan ile \% 5.2'lik kısmını oluşturmaktadır. Profil içerisinde bazik katyonların ve kirecin yıkanmasının yanı sıra, silikat killerin yüzey ve yüzeye yakın katmanlardan yıkanarak alt katlara illuviye olması sonucu argillic horizon oluşumu belirlenmiştir. Yüzeyde kil oranı \% 29'larda iken, bu oran derinlik artışına paralel olarak \% 64'lere ulaşmaktadır. Toprakların en önemli sorunu fazla suyun ortamdan uzaklaşamadığı drenaj problemidir. Toprak reaksiyonu hafif asit ile orta asit arasında değişmektedir. Organik madde içerikleri, profilde derinlik arttıça azalma göstermektedir. Topraklarda tuzluluk ve erozyon problemleri yoktur (Tablo 1 ve 2).

Kumlu kil tınlı alüviyal depozit ana materyalli taşkın alanlar üzerine oluşmuş Çaymahallesi serisi toprakları, toplam alan içerisinde 389.9 ha alan ile \% 7.3'lük kısmını oluşturmaktadır. Diğer bazı serilerde olduğu gibi tüm profil orta bünyeli ve geçirgenlikleri iyi olmalarına karşın, yılın uzun bir dönemi taban suyu ve sel taşkın etkileri sonucu topraklarda drenaj problemi ile karşı karşıya kalmaktadırlar. Bünye yüzey topraklarında kumlu kil tın, derinlere doğru özellikle kum ve silt oranlarındaki değişim sonucu tın, kil tın ve tekrar kumlu kil tın olmaktadır. Toprak reaksiyonu hafif asit reaksiyonlu olup, profil içerisinde homojenlik göstermektedir. Organik madde içerikleri, profilde derinlik arttıç̧a azalma göstermektedir. Topraklarda tuzluluk ve erozyon problemleri yoktur (Tablo 1 ve 2).

\subsection{Araştırma alanları topraklarının toprak taksonomisi ve FAO/ISRIC'e göre sınıflandırılması}

Çalışma alanı toprakları arazide yapılan morfolojik çalışmaların yanı sıra laboratuvar analiz sonuçları da dikkate alınarak 7. Yaklaşım veya Toprak Taksonomisi (Anonymous, 1999)'ne göre; 4 ordo, 6 altordo, 8 büyük grup ve 10 alt grup içerisine yerleştirilmiştir (Tablo 3). Araştırma alanında yer alan toprakların rutubet rejimleri Ustic ve sicaklik rejimleri ise Mesic'tir. Toprakların toprak taksonomisine göre sinıflandırılması, toprakların pedogenetik

Tablo 3. Çalışma alanı toprak serilerinin Toprak Taksonomisi (Anonymous, 1999) ve FAO/ISRIC (Anonymous, 2006)'a göre sinıflandirması

\begin{tabular}{|c|c|c|c|c|c|}
\hline \multirow{2}{*}{ Seri ad 1} & \multicolumn{4}{|c|}{ Toprak Taksonomisi } & \multirow{2}{*}{ FAO/ISRIC } \\
\hline & Ordo & Alt ordo & Büyük grup & Alt grup & \\
\hline Terme Çayı & \multirow[b]{2}{*}{ Entisol } & Fluvent & Ustifluvent & Typic Ustifluvent & Skeletic Fluvisol \\
\hline $\begin{array}{l}\text { Altunlu } \\
\text { Çangalar }\end{array}$ & & Aquent & $\begin{array}{c}\text { Fluvaquent } \\
\text { Psammaquent }\end{array}$ & $\begin{array}{c}\text { Vertic Fluvaquent } \\
\text { Mollic Psammaquent }\end{array}$ & $\begin{array}{l}\text { Clayic Fluvisol } \\
\text { Eutric Gleysol }\end{array}$ \\
\hline $\begin{array}{l}\text { Sarayköy } \\
\text { Güneydibağdat } \\
\text { Çardak }\end{array}$ & \multirow[t]{3}{*}{ Inceptisol } & \multirow[t]{2}{*}{ Ustept } & Haplustept & $\begin{array}{l}\text { Fluventic Haplustept } \\
\text { Calcic Haplustept } \\
\text { Aquic Haplustept }\end{array}$ & $\begin{array}{c}\text { Fluvic Cambisol } \\
\text { Calcaric Cambisol } \\
\text { Gelistangnic Cambisol }\end{array}$ \\
\hline Mescitli & & & Calciustept & Vertic Calciustept & Calcaric Cambisol \\
\hline Çaymahallesi & & Aquept & Epiaquept & Fluventic Epiaquept & Fluvic Cambisol \\
\hline $\begin{array}{l}\text { Şehli } \\
\text { Dibekli }\end{array}$ & Vertisol & Ustert & Haplustert & $\begin{array}{l}\text { Typic Haplustert } \\
\text { Chromic Haplustert }\end{array}$ & $\begin{array}{l}\text { Haplic Vertisol } \\
\text { Chromic Vertisol }\end{array}$ \\
\hline Yenimahalle & Alfisol & Ustalf & Haplustalf & Typic Haplustalf & Haplic Luvisol \\
\hline
\end{tabular}


özellikleri ile üst tanı horizonları (epipedon) ve bunların altında bulunan yüzey altı tanı horizonları ve özelliklerine göre yapılmıştır. Toprakların oluşum süreci sonrasında oluşan bazı yüzey üstü ve yüzey altı tanı horizonları saptanmış ve bunlar Entisol, Inceptisol, Alfisol ve Vertisol ordolarina yerleştirilmiştir. $\mathrm{Bu}$ ordolar içerisinde \% 55.3 ile Inceptisoller en fazla alan kaplarken, bunu sirasiyla \% 30.6 ile Entisoller, \% 8.9 ile Vertisoller ve $\% 5.2$ ile de Alfisoller izlemektedir. FAO/ISRIC (Anonymous, 2006)'e göre ise, Luvisol, Fulvisol, Cambisol, Gleysol ve Vertisol olarak sınıflandırılmıştır (Tablo 3).

Terme Çayı, Altunlu ve Çangalar serileri, Terme Çayı'nın zamanla getirmiş olduğu sedimentler üzerinde oluşmuş topraklardır. $\mathrm{Bu}$ serilere ait topraklar henüz herhangi bir yüzey altı tanı horizonunun oluşması için yeterli pedogenetik sürecin geçmemiş ve genç olmaları nedeniyle Entisol ordosu olarak sınıflandırılmıştır. Terme Çayı serisi fluventic özellikler göstermesi nedeniyle fluvent alt ordosuna karşılık Altunlu ve Çangalar serilerine ait topraklar yılın büyük bir bölümü yüksek taban suyu etkisi altında olmaları nedeniyle Aqent alt ordosuna ayrılmışlardır. Terme Çayı serisi büyük grup düzeyinde Ustifluvent ve büyük grubun tüm özelliklerini içermesi nedeniyle de Typic Ustifluvent alt gruba yerleştirilmiştir. FAO/ISRIC (Anonymous, 2006) siniflama sistemine göre ise; bu topraklar $1 \mathrm{~m}$ derinlik içerisinde \% 35'ten fazla iri çakıllı depozitler içermeleri nedeniyle Fluvisollerden Skeletic Fluvisol sınıfı içerisinde gösterilmiştir. Aquent alt ordosundaki Altunlu ve Çangalar serileri büyük grup düzeyinde farklılıklar içererek, Altunlu serisi Fluvaquent büyük grubuna, Çangalar serisi ise kaba materyalin \% 35'ten az ve ince kum ve silt içeriği yüksek alüviyal materyal içermeleri ile Psammaquent büyük grubuna yerleştirilmiştir. Alt grup düzeylerinde ise bu topraklar yüzeyde vertiklik özellikler taşıyan Altunluseris Vertic Fluvaquent olarak, Çangalar serisi ise yüzey toprağında mollic özellik göstermesi nedeniyle de Mollic Psammaquent olarak sınıflandırılmıştır. FAO/ISRIC (Anonymous, 2006) siniflama sistemine göre ise; Altunlu ve Çangalar serileri Clayic Fluvisol ve Eutric Gleysol olarak sınıflandırılmıştır (Tablo 3).

Sarayköy, Güneydibağdat, Çardak, Mescitli, ve Çaymahallesi serileri içerdikleri tanı horizonu ile (cambic), Entisollerden daha ileri bir toprak oluşumu göstermeleri nedeniyle Inceptisol ordosuna ve toprak nem rejiminin ustic olması sonucu Ustept alt ordosuna, Çaymahallesi serisi ise Aquept alt ordosuna yerleştirilmişlerdir. Sarayköy, Çardak ve Güneydibağdat serileri $100 \mathrm{~cm}$ derinlik içerisinde bir fragipan veya duripan içermemeleri ve aynı derinlik içerisinde calcic veya petrocalcic horizonlarının olmaması nedeni ile Haploxerept büyük grubuna; Mescitli serisi ise, $100 \mathrm{~cm}$ derinlik içerisinde calcic horizon bulunması nedeniyle Calciustept büyük grubuna ve Çaymahallesi serisi ise Epiaquept büyük grubunda gösterilmiştir. Sarayköy, Güneydibağdat, Çardak, Mescitli ve Çaymahallesi serileri alt grup düzeylerde ise sirasiyla Fluventic Haplustept, Calcic Haplustept, Aquic Haplustept, Vertic Calciustept ve Fluventic Epiaquept olarak sınıflandırılmıştır. FAO/ISRIC (Anonymous, 2006) siniflama sistemine göre ise; Fluvic, Calcaric, Gelistangnic, Calcaric Cambisol olarak sınıflandırılmıştır (Tablo 3).

Şehli ve Dibekli serileri ait toprakları da şişme özelliğindeki killerin miktarı çok fazla olması (profil boyunca \% 40 ve daha fazla), kurak mevsimlerde yüzeyden derinlere uzanan çatlaklara sahip olmaları ve profil içerisinde yer yer kayma yüzeylerin görülmesi nedeni ile Vertisol ordosuna yerleştirilmiştirler. Toprak nem rejimi ustic olması nedeni ile Ustert alt ordosuna, her iki seri toprakları da zayıf vertisol gelişimi nedeni ile Haplustert büyük grubunda sınıflandırılmıştır. Alt grup düzeyinde ise Şehli serisine ait toprakla büyük grubunun tüm özelliklerini taşımaları nedeniyle Typic Haplustert, Dibekli serisi ise Chromic Haplustert olarak sınıflandırılmıştır. Bu serilerin FAO/ISRIC (Anonymous, 2006) sınıflama sistemine göre ise Haplic Vertisol ve Chromic Vertisol olarak sınıflandırılmıştır (Tablo 3).

Argillik horizon oluşturacak kadar ileri düzeyde profil gelişimi gösteren ve baz doygunluklarının yüksek seviyelerde olması nedeniyle Yenimalle serisi topraklar Alfisol ordosuna, toprak nem rejiminden dolay Ustalf alt ordosuna ve diğer büyük gruplara girmedikleri için Haploustalf büyük grubuna dahil edilmişlerdir. Alt grup düzeyinde ise büyük grubunun tüm özelliklerini içermeleri nedeniyle Typic Haplustalf olarak sinıflandırılmıştır. FAO/ISRIC (Anonymous, 2006) sinıflama sistemine göre ise Haplic Luvisol olarak sınıflandırılmıştır (Tablo 3).

\section{Kaynaklar}

Anonymous, 1992. Soil Survey Staff, Procedures for Collecting Soil Samples and Methods of Analysis for Soil Survey. Soil Survey Investigations Report No. 1, USDA, U.S. Government Printing Office, Washington, DC., USA.

Anonymous, 1993. Soil Survey Staff, Soil Soil Survey Manual. USDA, Handbook No: 18, Washington, DC.

Anonymous, 1999. Soil Survey Staff, Soil Taxonomy: A Basic System of Soil Classification for Making and Interpreting Soil Surveys. USDA, Handbook No: 
436, U.S. Government Printing Office, Washington, DC.

Anonymous, 2006. FAO/ISRIC. World References Base for Soil Resources. World Soil Rep., 103. Rome.

Blake, G.R., Hartge, K.H., 1986. Bulk Density and Particle Density. In: A. Klute (Ed), Methods of Soil Analysis: Part 1-Physical and Mineralogical Methods, Soil Science Society of America, American Society of Agronomy, Madison, pp. 363381.

Bouyocous, G.J., 1951. A recalibration of the hidrometer method for making mechanical analysis of soils. Agronomy Journal, 43: 435-438.

Dengiz, O., Öztürk, E., Sarığlu, E., 2010. Alüviyal taşkın ovada morfometrik esaslara göre toprakların sınıflama ve haritalama çalıșması: CarșambaDikbıyık Beldesi. I. Ulusal Toprak ve Su Kaynakları
Kongresi, 1-4 Haziran, Eskişehir, s. 351-361.

Jackson, M.L., 1958. Soil Chemical Analysis. Prence Hall Inc., Engleewood Cliffs, NJ. USA.

Rhoades, J.D., 1982. Cation Exchange Capacity. In: A.L. Page (Ed), Methods of Soil Analysis: Part 2Chemical and Microbiological Properties (2nd ed.), ASA and SSSA Agronomy Monograph No 9, Madison, pp. 149-157.

Richards, L.A., 1954. Diagnosis and Improvement of Saline and Alkalin Soils. U.S. Dept. Agr., Handbook, 60, 109, Riverside.

Yılmaz, E., 2005. Bir arazi kullanım planlaması modeli: Cehennemdere Vadisi örneği. T.C. Çevre ve Orman Bakanlığı, Doğu Akdeniz Ormancılık Araştırma Müdürlügü, Çevre ve Orman Bakanlığı Yayın No: 253, DOA Yayın No: 37, Çeşitli Yayın No: 3, Tarsus. 